UDC 620.9

SCOPUS CODE 2101

https://doi.org/10.36073/1512-0996-2021-3-59-68

\title{
Criteria for Estimating Greenhouse Gas Emissions from Transport
}

\section{Maka Jishkariani Department of Electric Energy and Electro Mechanics, Georgian Technical University,} Georgia, 0160, Tbilisi, 75 M. Kostava str.

\section{Reviewers:}

N. Samsonia, Professor, Faculty of Energy and Telecommunications, GTU

E-mail: n.samsonia@gtu.ge

K. Vezirishvili-Nozadze, Professor, Faculty of Energy and Telecommunications, GTU

E-mail: k.vezirishvili-nozadze@gtu.ge

\begin{abstract}
At the present stage, economic research on climate change and its main problem requires in-depth scientific study and analysis of various factors. An important source of air pollution is the energy sector, especially solid and liquid fuels used for technological purposes in thermal power plants. In Georgia, $1 / 5$ of the total electricity generated is produced in thermal power plants. The article analyses Greenhouse gas emissions in Georgia by sectors and sub-sectors as well the criteria for estimating fuel combustion, such as net calorific value of fuel and carbon content standard indicators. The formula for calculation of $\mathrm{CO}_{2}, \mathrm{CH}_{4}$ and $\mathrm{N}_{2} \mathrm{O}$ emissions from the transport vehicles is developed in this work.
\end{abstract}

Key words: fuel combustion; greenhouse gases; power engineering; transport.

\section{Introduction}

At the present stage, economic research on climate change and its main problem requires in-depth scientific study and analysis of various factors, without which it is impossible to properly understand the essence of economic events, identify key factors, identify development trends and ways of their further improvement. An important source of air pollution is the energy sector, especially, solid and liquid fuels used for technological purposes in thermal power plants. In Georgia, 1/5 of all generated electricity is produced at thermal power plants (TPP), while the cooling reservoir causes thermal pollution of the river. The products of industrial production in today's world provide many greenhouse gases, such as metals, chemical production and use, cement production and many other. [1]. Traffic jams and exhaust on top of cities are notable. Arguably the most visible source of emissions comes from transport. These are: aviation, rail and road transport. The share of electric and hybrid cars in Georgia is growing, but not enough. Processes such as volatile emissions are important. Before the fuel burns, it already emits emissions into the atmosphere, such as emissions from oil refining products and methane leaks, which are serious and difficult issues to address [2].

\section{Main part}

Greenhouse gas emissions in Georgia by sectors and 
sub-sectors show that the energy sector, including the transport sub-sector, occupies the first place with 57\%, or almost $60 \%$. In the second place are industrial production processes with $18 \%$ and in the third place is agriculture with 17\% in 2019 (table 1).

Table 1

Greenhouse gas emissions in Georgia by sectors and sub-sectors

\begin{tabular}{|l|l|c|}
\hline 1 & Energy (including Transport sub sector) & 57 \\
\hline 2 & Industrial Processes & 18 \\
\hline 3 & Solvents and other products Consumption & 4 \\
\hline 4 & Rural industry & 17 \\
\hline 5 & Land use and forestry & 3 \\
\hline 6 & Waste & 1 \\
\hline 7 & Other & 0.0001 \\
\hline & Percent, sum & 100 \\
\hline
\end{tabular}

The energy sector considers fuel combustion in the energy industry, transport, manufacturing and building materials, as well as in segments such as commercial, public, household and public facilities, agriculture, fisheries and forestry [3]. In the same sector, volatile emissions from solid, liquid and gaseous fuels are considered. Analysis show that GHG emissions among energy sector, the largest share comes from the transport subsector 33\% in Georgia in 2019 (table 2).

Table 2

Greenhouse gas emissions in the energy sector of Georgia

\begin{tabular}{|l|l|c|}
\hline & Fuel Combustion & 10 \\
\hline 1 & Energy Industry (Electricity and Heat Generation) & 21 \\
\hline 3 & Processing Industry and Construction Materials Industry & 33 \\
\hline 4 & Transport & 15,7 \\
\hline & Other Sectors (trade/ household/rural industry/fishing/forestry) \\
\hline 1 & Volatile Emissions from Fuel & 1,1 \\
\hline 2 & Solid Fuel & 19,2 \\
\hline
\end{tabular}

Because the contribution of transport to climate change is significant, we examined the quantities of passenger cars, buses, minibuses, agricultural and freight vehicles (figure 1), and passenger and cargo turnover statistics to determine their impact on the final rate, or greenhouse gas emissions [4]. 


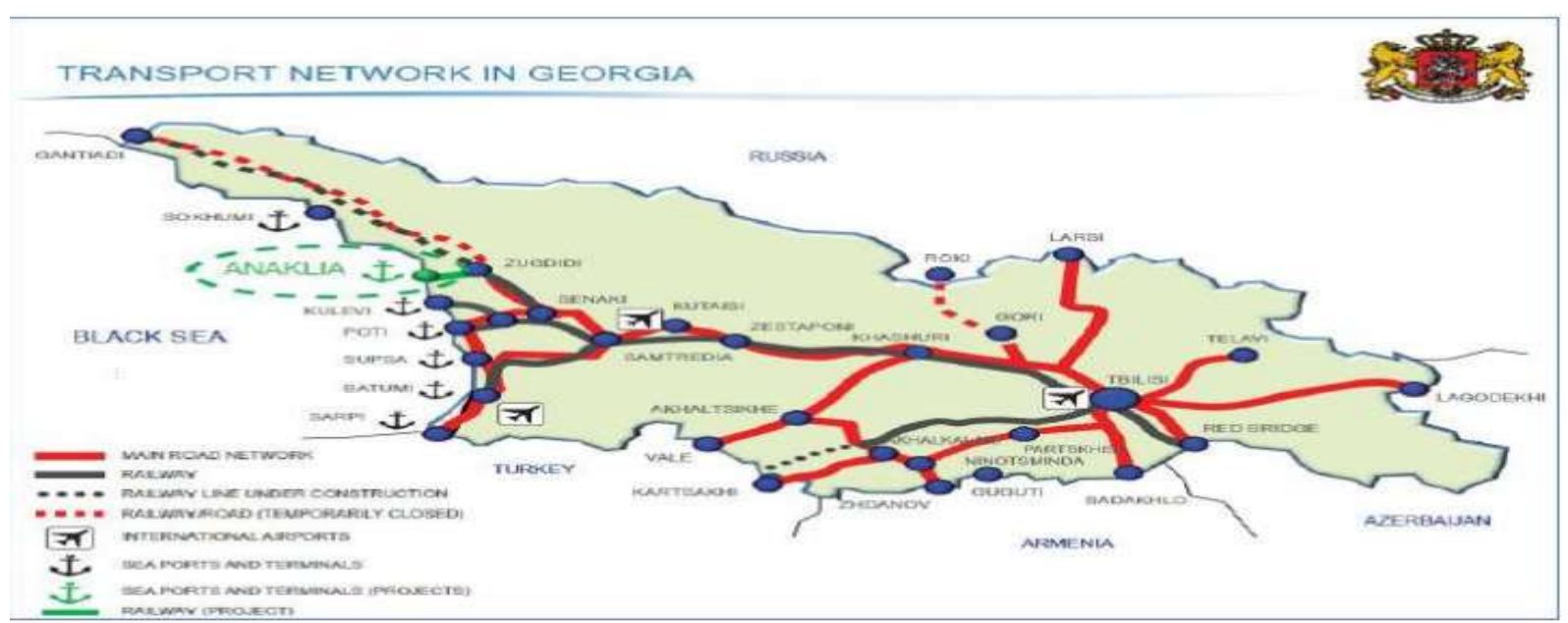

Figure 1. Transport Network in Georgia

The passenger turnover rate for 2019 includes total data on road, rail, river, sea and air transport [5]. The growth trend of this indicator is mainly due to the increase in passenger traffic, for example, in 2019, almost $80 \%$ of passengers traveled by road (using non-ecological fuel), which has a negative impact on climate change. If we analyze the percentage distribution of vehicles in Georgia in 2019, the largest share comes from cars, from which electric cars are only $4-5 \%$. The freight rate for 2019 includes aggregate road, rail, river, sea and air transport data [6]. The downward trend in this indicator is mainly due to the decrease in rail shipments [7]. It should be noted that rail transport accounts for the largest share in terms of freight transport, for example, in 2019, 78\% of cargo turnover was accounted by rail transport. One way to reduce greenhouse gases from transport is to use biofuels as fuel [8]. The most common types of bio fuels are biodiesel and bioethanol. Biodiesel creation process takes place in the device, where crops [9], like rape and sunflower are high pressure conditions and will be received combined food, in the inner tank squeezed oil from the reservoir is transferred to the device in the second section, where added oxide, then this mixture goes in generator, where in conditions of high pressure and high temperature is occurred biochemical reaction and about half an hour being taken biodiesel, which can be used in any diesel engine [10].
Bioethanol is made from corn or sugar cane, or from high concentration sugar or starch products such as beet, potato, Manioc. Ethanol is substance, which is received by the fermentation, and it usually interferes with gasoline to increase octane level [11] Increase the fuel octane level which is necessary to improve the combustion process, until recently used very high toxic substance. Thus, bioethanol as well as a carbon neutral fuel, is considered more environmentally acceptable alternative [12]. Biofuel use in the transport sector must be executed by the methodology approved by the Executive Board of the Clean Development Mechanism [13]. Projects must be performed based on the methodology, approved by Clean Development Mechanism (CDM) Executive Board. For Georgia is used Consolidated Methodology of Baseline Level ACM0017 „,Production of Biodiesel for Use as Fuel”[14].

\section{Materials and Research Methods}

Each type of fuel has a heat of combustion or calorific value that are represented in special manuals [15], but if this data is not available, standard indicators should be used, from the guideline document - 2006 IPCC Guidelines for National Greenhouse Gas Inventories [16], (table 3). 
Table 3

Net Calorific Value (NCV) of Fuel

\begin{tabular}{|l|l|}
\hline Fuel Type Description & Net Calorific Value (NCV), $(\mathrm{kJ} / \mathrm{kg})$ \\
\hline Gasoline & 44300 \\
\hline Diesel & 43000 \\
\hline Natural Gas & 48000 \\
\hline Crude oil & 42300 \\
\hline Liquefied natural gas & 44200 \\
\hline Aviation Gasoline & 44300 \\
\hline Kerosene & 43800 \\
\hline Ethan & 46400 \\
\hline Napta & 44500 \\
\hline Bitumen & 40200 \\
\hline Anthracite & 26700 \\
\hline Lignite & 11900 \\
\hline Cox & 28200 \\
\hline Firewood & 15600 \\
\hline Other solid biomass & 11600 \\
\hline Wood charcoal & 29500 \\
\hline Biodiesel & 27000 \\
\hline Other liquid biofuels & 27400 \\
\hline Landfill gas & 50400 \\
\hline Other Biomass Gas & 50400 \\
\hline
\end{tabular}

Each type [17] of fuel has a carbon content data but if this data is not available, should be used standard indicators, from the guideline document - 2006 IPCC
Guidelines for National Greenhouse Gas Inventories [18], (table 4).

Table 4

Carbon Content Data

\begin{tabular}{|l|l|}
\hline Fuel Type Description & Carbon, C (Kg/GJ) \\
\hline Gasoline & 18,9 \\
\hline Diesel & 20,2 \\
\hline Natural Gas & 15,3 \\
\hline Crude oil & 20 \\
\hline Liquefied natural gas & 17,5 \\
\hline Aviation Gasoline & 19,1 \\
\hline Kerosene & 19,6 \\
\hline Ethan & 18,6 \\
\hline Napta & 20 \\
\hline Bitumen & 22 \\
\hline Anthracite & 26,8 \\
\hline Lignite & 27,6 \\
\hline Cox & 29,2 \\
\hline Firewood & 30,5 \\
\hline Other solid biomass & 27,3 \\
\hline Wood charcoal & 30,5 \\
\hline Biodiesel & 19,3 \\
\hline Other liquid biofuels & 21,7 \\
\hline Landfill gas & 27,3 \\
\hline Other Biomass Gas & 14,9 \\
\hline
\end{tabular}




\section{Conclusion}

\section{Results and Their Discussions}

To calculate Carbon dioxide $\left(\mathrm{C}_{2} \mathrm{O}\right)$ emissions consumed by vehicles, needed the country - specific net calorific values are needed (NCV kJ/kg) [19], fuel carbon content (C/Joule) and oxidation coefficient (Oxide Rate,
$\%)$, if this data is not available, use standard indicators [20], from the guideline document - 2006 IPCC Guidelines for National Greenhouse Gas Inventories, (table 5) $[21]$.

Table 5

\section{$\mathrm{C}_{2} \mathrm{O}$ Emission Coefficient Calculation}

\begin{tabular}{|l|l|l|l|}
\hline Fuel Type Description & Carbon, $(\mathrm{kg} / \mathrm{GJ})$ & Oxide Rate, $(\%)$ & Emission Coefficient $\mathrm{C}_{2} \mathrm{O},(\mathrm{kg} / \mathrm{TJ})$ \\
\hline 1 & 2 & 3 & $4=\left(2^{*} 3^{*} 44 / 12\right)^{*} 1000$ \\
\hline Gasoline & 18,9 & 1 & 69300 \\
\hline Diesel & 20,2 & 1 & 74100 \\
\hline Natural Gas & 15,3 & 1 & 56100 \\
\hline Crude oil & 20 & 1 & 73300 \\
\hline Liquefied natural gas & 17,5 & 1 & 64200 \\
\hline Aviation Gasoline & 19,1 & 1 & 70000 \\
\hline Kerosene & 19,6 & 1 & 71900 \\
\hline Ethan & 18,6 & 1 & 61600 \\
\hline Napta & 20 & 1 & 73300 \\
\hline Bitumen & 22 & 1 & 80700 \\
\hline Anthracite & 26,8 & 1 & 98300 \\
\hline Lignite & 27,6 & 1 & 101000 \\
\hline Cox & 29,2 & 1 & 107000 \\
\hline Firewood & 30,5 & 1 & 112000 \\
\hline Other solid biomass & 27,3 & 1 & 100000 \\
\hline Wood charcoal & 30,5 & 1 & 112000 \\
\hline Biodiesel & 19,3 & 1 & 70800 \\
\hline Other liquid biofuels & 21,7 & 1 & 79600 \\
\hline Landfill gas & 27,3 & 1 & 100000 \\
\hline Other Biomass Gas & 14,9 & 1 & 54600 \\
\hline
\end{tabular}

To calculate $\mathrm{CH}_{4}$ and $\mathrm{N}_{2} \mathrm{O}$ emissions using transport there is needed a particular data of consumed fuel and fuel carbon content (C/Joule) [22], if this data is not available, the calculations will be performed at the level
I approach from the guideline document - 2006 IPCC Guidelines for National Greenhouse Gas Inventories [23], (table 6).

Table 6

Calculation of $\mathrm{CH}_{4}$ and $\mathrm{N}_{2} \mathrm{O}$ emissions from the transport

\begin{tabular}{|l|l|l|}
\hline \multicolumn{1}{|c|}{$\mathrm{CH}_{4}, \mathrm{~kg} / \mathrm{TJ}$} & \multicolumn{1}{c|}{$\mathrm{N}_{2} \mathrm{O}, \mathrm{kg} / \mathrm{TJ}$} \\
\hline Gasoline & 33 & 3,2 \\
\hline Diesel & 3,9 & 3,9 \\
\hline Compressed natural gas & 92 & 3 \\
\hline Liquefied natural gas & 62 & 0,2 \\
\hline Ethan & 260 & 41 \\
\hline
\end{tabular}


$\mathrm{CO}_{2}$-emissions assessment for road transport is carried out by the following formula [24]:

$\mathrm{CO}_{2}$ emission $=\sum$ Fuel $(a) * E f(a)$

Where - $\mathrm{CO}_{2}$ emissions (tons); Fuel(a) - used (consumed) Fuel (TJ); Ef(a) - the emission coefficient $\mathrm{CO}_{2}(\mathrm{~kg} / \mathrm{TJ}) ; \mathrm{a}-\mathrm{a}$ type of greenhouse gas [25].

Despite the many positive changes that have taken place in Georgia in recent years, the transport sub-sector still needs to take steps to ensure a gradual transition to European fuel standards, renewal of city transport parks, regulation of second-hand car imports, vehicle inspections and other transport-related measures for climate change related problem solving [26]. Implementing energy efficiency measures, using renewable energy sources to generate electricity, developing high-tech equipment, introducing fuel standards and tightening regulations, replacing and upgrading old equipment in industrial facilities, technical inspections and renovations of all vehicles By introducing construction norms, reducing product packaging, introducing energy efficient technologies in the processing industry and building materials production, replacing the old natural gas transportation and distribution pipes, etc. It is possible to significantly reduce greenhouse gas emissions, which is undoubtedly a contributing factor in reducing climate change [27].

\section{References}

1. Jishkariani, M., Dvalishvili, N., Kurakhchishvili, L. (2020). Evaluation of Calorific of Municipal Solid Waste (MSW). In: Ghosh, S. (eds.) Sustainable Waste Management: Policies and Case Studies. Singapore: Springer, 263-265. https://doi.org/10.1007/978-981-13-7071-7_23. (In English);

2. Jishkariani, M. (2019). Electricity Tariffs in Georgia. Warsaw, Poland: World of Science 9(49), pp.20-22. Vol.1.doi:10.31435/rsglobal_ws/30092019/6697. (In English);

3. Jishkariani, M. (2019). Establish of Energy Efficiency Passports for Private Property Owners, Small and Medium Businesses. Retrieved from ResearchGate:

https://www.researchgate.net/publication/335620279_Establish_of_Energy_Efficiency_Passports_for_Private_P roperty_Owners_Small_and_Medium_Businesses. (In English);

4. Jishkariani, M. (2020). Safety Rules for Power Engineering Companies. Retrieved from Research Gate: https://www.researchgate.net/publication/342233298_Safety_Rules_for_Power_Engineering_Companies. (In English);

5. Jishkariani, M. (2020). Failure Mode and Effect Analysis in Energy Companies. Retrieved from ResearchGate: https://www.researchgate.net/publication/341914208_Failure_Mode_and_Effect_Analysis_in_Energy_Compani es. (In English);

6. Jishkariani, M. (2020). Fault Tree Analysis (FTA) For Energy Enterprises. Retrieved from ResearchGate: https://www.researchgate.net/publication/341494947_Fault_Tree_Analysis_FTA_For_Energy_Enterprises. (In English);

7. Jishkariani, M. (2020). Risk Management and Losses Calculation in Energy Enterprises. Retrieved from ResearchGate:

https://www.researchgate.net/publication/341130738_Risk_Management_and_Losses_Calculation_in_Energy_ Enterprises. (In English);

8. Jishkariani, M. (2020). Load Measurement Forms and Reliability of Power Supply Systems. Retrieved from ResearchGate:

https://www.researchgate.net/publication/340234067_Load_Measurement_Forms_and_Reliability_Of_Power_S upply_Systems. (In English); 
9. Jishkariani, M., Tsotskhalashvili, S. (2020). Features of Electricity Pricing in Georgia. Georgia, Tbilisi: Energy, \#4(96), 188-190. Retrieved from ResearchGate:

https://www.researchgate.net/publication/348975571_Features_of_Electricity_Pricing_in_Georgia., (In English);

10. Jishkariani, M., Tsotskhalashvili, S. (2021). Using Google Sheets to Analyze Electricity Tariffs. World science: Problems, Prospects and Innovations. Abstracts of the 5th International scientific and practical conference. Toronto, Canada: Perfect Publishing, 97-101.

URL:https://sci-conf.com.ua/v-mezhdunarodnaya-nauchno-prakticheskaya-konferentsiya-world-scienceproblems-prospects-and-innovations-27-29-yanvarya-2021-goda-toronto-kanada-arhiv/., (In English);

11. Bochorishvili, L., Topuria, M., Jishkariani, M. (2020). Features of Preparing Students in Economic Disciplines in Higher Technical Schools. Georgian Academy of Education Sciences. pp.78-84. Retrieved from ResearchGate: https://www.researchgate.net/publication/348944253_Features_of_Preparing_Students_in_Economic_Disciplin es_in_Higher_Technical_Schools. (In English);

12. Vezirishvili-Nozadze, K., Jishkariani, M., Pantskhava, E. (2021). Energy Efficiency - The Most Important Factor in Increasing The Country's Energy Independence. The World of Science and Innovation. Abstracts of the $7^{\text {th }}$ International Scientific and Practical Conference. London, United Kingdom: Cognum Publishing House. 132-140.

URL:https://sci-conf.com.ua/vii-mezhdunarodnaya-nauchno-prakticheskaya-konferentsiya-the-world-ofscience-and-innovation-10-12-fevralya-2021-goda-london-velikobritaniya- arhiv /. (In English);

13. Vezirishvili-Nozadze, K., Jishkariani, M., Pantskhava, E. (2021). Climate Change Impact Assessment on Energy. Ankara, Turkey: Middle East $5^{\text {th }}$ International Conference on Contemporary Scientific Studies, March 27-28, 2021. Vol.1., 369-376. ISBN-978-625-7898-38-6.

URL:https://www.researchgate.net/publication/350890344_Climate_Change_Impact_Assessment_on_Energy. (In English);

14. Vezirishvili-Nozadze, K., Jishkariani, M., Pantskhava, E. Renewable and non-Traditional Energy Sources. Actual trends of modern scientific research. Munich, Germany: MDPC Publishing, Abstracts of the 8th International scientific and practical conference. 232-239.

URL:https://sciconf.com.ua/viii-mezhdunarodnaya-nauchno-prakticheskaya-konferentsiya-actualtrends-ofmodern-scientific-research-14-16-marta-2021-goda-myunhen-germaniyaarhiv/. 2021, (In English);

15. Vezirishvili-Nozadze, K., Jishkariani, M., Pantskhava, E. (2021). Impact of Climate Change on Georgia's Energy Sector - Vulnerability and Adaptation. Science and Education: Problems, Prospects and Educations. Proceedings of the $7^{\text {th }}$ International Scientific and Practical Conference. Kyoto, Japan: CPN Publishing Group. 175-183.

URL:https://sci-conf.com.ua/vii-mezhdunarodnaya-nauchno-prakticheskaya-konferentsiya-science-andeducation-problems-prospects-and-innovations-1-3-aprelya-2021-goda-kioto-yaponiya-arh/.(In English);

16. Jishkariani, M., Tsotskhalashvili, S. (2021). Waste Processing for Energy Purposes in Georgia. Turkey: International Black Sea Coastline Countries Scientific Research Symposium-VI, 66-72.

URL:https://b0699d12-70ad-4313-

81f10833a431c01a.filesusr.com/ugd/614b1f_c5741b3ac1fd47c59f016a15d6b80a25.pdf.(In English);

17. Gudiashvili, M., Gagua, A. (2018). Elaboration of a Forecast Model for Carbon Dioxide Emissions. Georgia, Tbilisi: GTU, Collection of Scientific Works 3(509), 107-115.

http://shromebi.gtu.ge/storage/archit/119/shroma-3509.pdf. (In English);

18. Gudiashvili, M., Gagua, A. (2017). Climate Change and Emissions Trading Tendencies. Tbilisi, Georgia: Business Engineering 3, 334-337.

URL:https://drive.google.com/file/d/1yD0cz0rr1ivo4seRgXUMHnVmCweSDbzF/view (In English); 
19. Sabelashvili, T., Gudiashvili, M., Radmehr, M. (2016). Biomass Heating System Project. Tbilisi: GTU, Collection of Scientific Works, 3(501), 78-83.

URL:http://shromebi.gtu.ge/storage/archit/71/pdf-1490183445-Kz9cerQA71B5baTSfxNbeWz84dk8Mca.pdf (In English);

20. Chachibaia, G., Samsonia, N., Gudiashvili, M. (2016). Impact of Georgian Project Hydro Power Stations on Climate Change. Tbilisi: GTU, Collection of Scientific Works, 3(501), 69-77.

URL:http://shromebi.gtu.ge/storage/archit/71/pdf-1490183445-mKz9cerQA71B5baTSfxNbeWz84dk8Mca.pdf (In Georgian);

21. Gudiashvili, M., Lomidze, S. (2014). Modelling of the Structure of Georgian Electro System. Tbilisi: GTU, Collection of Scientific Works, 4(494), 9-14.

URL:http://shromebi.gtu.ge/storage/archit/8/pdf-1450228979-8XcIG8yXqzCm4gGlUUJDgEnkhHj30Agl.pdf (In Georgian);

22. Gudiashvili, M., Lomidze, S. (2013). Prognosis of Hydro Power Plant Energy Indicator by Using the Least Square Method. Business Engineering, 4, 126-127.

URL: https://drive.google.com/file/d/OB3PZSQNPT43Sa0xXUUwwRGNpMkE/edit (In English);

23. Gudiashvili, M. (2013). Software Modelling of a Small HPP Business Process. Tbilisi: GTU, Collection of Scientific Works, 3(489), 13-16.

URL:http://shromebi.gtu.ge/storage/archit/29/pdf-1466595685-sDHT1LSTrs4aB7hpyL2slNC6sstXcWo4.pdf (In English);

24. Gudiashvili, M. (2013). Decision Tree Method in Energy Management. Tbilisi, Georgia: Grigol Robakidze University Academic Digest - Business and Management, 1.

URL:http://phasis.tsu.ge/index.php/GRUNI_B/article/view/209/pdf. (In English);

25. Gudiashvili, M., Bzhalava, N., Jishkariani, T. (2007). Computer Modeling of Electricity Tariffs. Georgian Economics, 4(113), 70-72.

URL: http://geoeconomics.ge/?p=2806. (In Georgian);

26. Gudiashvili, M., Samsonia, N. (2006). The Issue of Expediency of New Tariffs of Electricity. Georgian Economics, 7-8(104-105), 68-69.

URL: http://geoeconomics.ge/?p=2417.(In Georgian);

27. Gudiashvili, M. (2005). Identification of Small Hydroelectric Plant Reserves with Chain Method. Georgia, Tbilisi: Georgian Economics, 7(92), 52-53

URL: http://geoeconomics.ge/?p=1897. (In Georgian); 


\section{UDC 620.9}

SCOPUS CODE 2101

https://doi.org/10.36073/1512-0996-2021-3-59-68

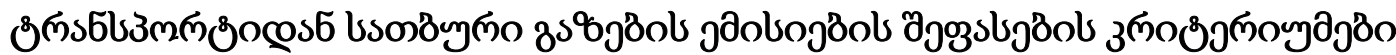

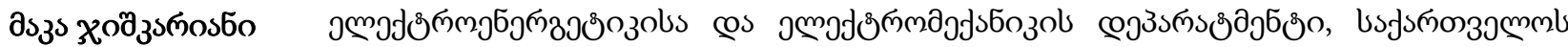

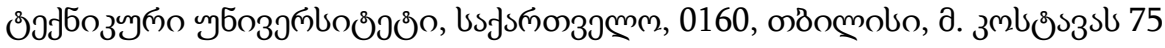

E-mail: m.gudiashvili@gtu.ge

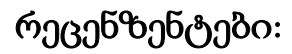

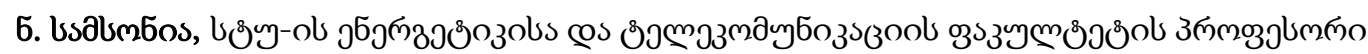

E-mail: n.samsonia@gtu.ge

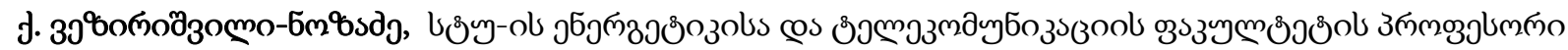

E-mail: k.vezirishvili-nozadze@gtu.ge

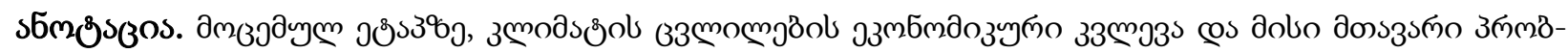

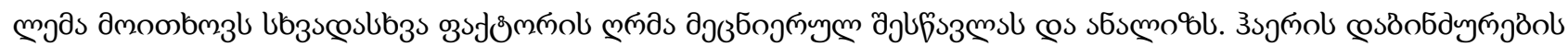

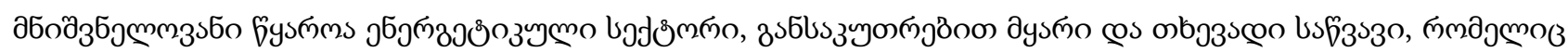

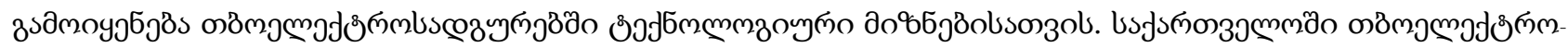

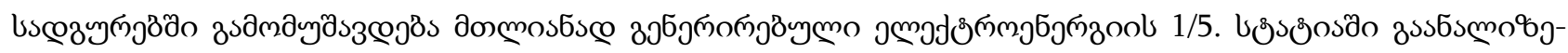

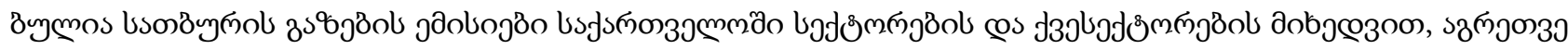

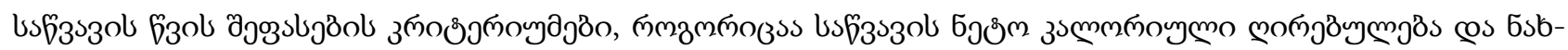

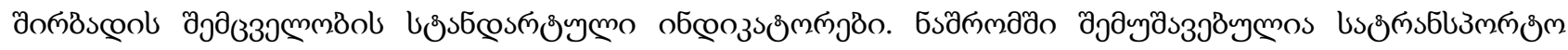

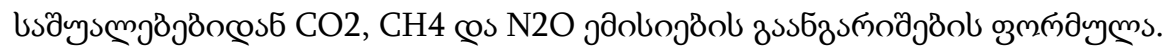

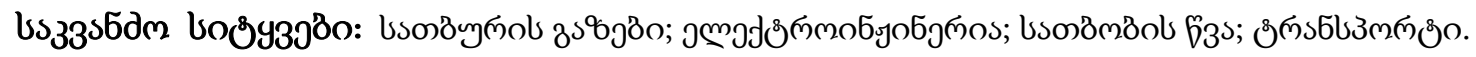




\section{UDC 620.9}

SCOPUS CODE 2101

https://doi.org/10.36073/1512-0996-2021-3-59-68

\section{Критерии оценки выбросов парниковых газов от транспорта}

Мака Джишкариани Департамента электроэнергетики и электромеханики, Грузинский технический университет, Грузия, 0160, Тбилиси, ул. М. Костава 75

E-mail: m.gudiashvili@gtu.ge

\section{Рецензенты:}

Н. Самсония, профессор факультета энергетики и телекоммуникаций ГТУ

E-mail: n.samsonia@gtu.ge

К. Везиришвили-Нозадзе, профессор факультета энергетики и телекоммуникаций ГТУ

E-mail: k.vezirishvili-nozadze@gtu.ge

\section{Аннотация.}

На современном этапе экономические исследования изменения климата и его основной проблемы требуют глубокого научного изучения и анализа различных факторов. Важным источником загрязнения воздуха является энергетика, особенно твердое и жидкое топливо, используемое в технологических целях на тепловых электростанциях. В Грузии 1/5 всей вырабатываемой электроэнергии производится на тепловых электростанциях. В статье анализируются выбросы парниковых газов в Грузии по секторам и подсекторам, а также критерии оценки сжигания топлива, такие как низшая теплотворная способность топлива и стандартные показатели содержания углерода. В статье разработана формула для расчета выбросов $\mathrm{CO} 2$, $\mathrm{CH} 4$ и $\mathrm{N} 2 \mathrm{O}$ от транспортных средств.

Ключевые слова: парниковые газы; сжигание топлива; транспорт электроэнергетика. 